\title{
Superintendent Response to the Financial DownturnT
}

\author{
Teresa Martin Starrett ${ }^{1}$, Pat Casey $^{2} \&$ Karen Dunlap ${ }^{1}$ \\ ${ }^{1}$ College of Professional Education, Texas Woman's University, USA \\ ${ }^{2}$ College of Education, University of Texas at Arlington, USA \\ Correspondence: Teresa Starrett, College of Professional Education, Texas Woman's University, PO Box \\ 425769, Denton, Texas 76204, USA. Tel: 1-940-898-2244. E-mail: tstarrett@twu.edu
}

Received: November 14, $2013 \quad$ Accepted: December 9, $2013 \quad$ Online Published: February 12, 2014

doi:10.5539/jel.v3n1p34 URL: http://dx.doi.org/10.5539/jel.v3n1p34

\begin{abstract}
In this study, 79 local school district leaders from the state of Texas were contacted and asked for their input relating to strategic practices used during an economic downturn. Findings describe how the recent funding cuts affected the varied districts; how the districts fared in comparison with similar districts in the area; steps the district took before and after budget cuts were mandated to ameliorate the financial situation; and strategies/procedures they wished the district had undertaken. Generally, leaders expressed pleasure in the way the downturn had been addressed by policies/strategies/personnel within their own district. The study offers helpful and interesting information to educational leaders who are faced with difficult economic circumstances.
\end{abstract}

Keywords: finance, Texas, superintendent, budget

\section{Introduction}

Spending on K-12 education has increased one-third in inflation-adjusted dollars since 1995 (Petrilli \& Roza, 2011). Coupled with a concurrent economic downturn, schools across the nation have been placed in situations where they are compelled to admit that funding cuts are all but inevitable (Ginsburg \& Multon, 2011). This study examines superintendents' responses to budget shortfalls in Texas.

In June 2011, the $82^{\text {nd }}$ Texas Legislature passed a budget that cut four billion dollars across the board from all school districts forcing school leaders to make difficult decisions. In September 2011, Texas Senate Bill 8 (SB8) became effective. This bill included provisions that increased a school district's flexibility in addressing anticipated or realized shortfalls (Walsh, Anderson, Brown, Gallegos, \& Green, 2011). For example, to meet lower spending mandates, districts were allowed to reduce salaries for classroom teachers, librarians, counselors and teachers and/or add unpaid furlough days to an annual schedule. In another move, the Texas legislature also granted its school districts the authority to non-renew teachers' contracts as late as 10 days prior to the start of the school year rather than the previously required 45-day rule.

\section{Literature}

\subsection{School Funding in Texas}

The Foundation School Program (FSP) establishes and provides state funding amounts in Texas. The FSP considers local resources and allocates state funds to equalize per student funding. School districts receive FSP funding designated for both operations and facilities. Operations funding provides districts the means by which to finance their maintenance and operations and is comprised of three components.

In general, Tier I funding is basic funding for educational services as it provides state assistance based on average daily attendance (ADA). An adjusted Tier I allotment is calculated using an array of weighted programs such as special education, bilingual education, and career/technical education. Tier II funding supplements basic funding based on a weighted average daily attendance (WADA). This funding source establishes a minimum per student amount. Some districts receive additional funding that compensates for property tax shortfalls and adjusts funding to meet statutory minimum per student funding requirements. Finally, the third funding component is the Instructional Facilities Allotment and Existing Debt Allotment which provides additional funding to districts so they may purchase/renovate facilities or receive assistance with related debt (Texas Education Agency [TEA], 2011). 
In summary, during the past 30 years, $\mathrm{K}-12$ state education funding in Texas has been through many changes as it strives to create a fair and equitable state-wide funding system (Imazeki \& Reschovsky, 2004). At the time of this study, Texas used a recapture method to equalize funding among school districts. If the district's property wealth exceeded the statutory property wealth per WADA, the district was subject to recapture to insure equitable allotments of educational funding statewide. Recapture requires districts to send money to the state in order to reduce property wealth per WADA (TEA, 2011). It should be noted as well that Texas state government follows a biannual model of legislative sessions. Therefore, continual legislative court battles ensue in an effort to establish a funding model that is effective and equitable for all (Bingham, 2008).

\subsection{Context/Background Information}

Federal funds come to school districts in the form of assistance for free and reduced-price lunches, technology, bilingual education, special education and special grants. It is difficult to total the amount of federal funding allocated to specific school districts as grants are apportioned through different agencies (United States Government Accountability Office, 2010). While funding for federal programs, such as Title I, comes directly from the federal government, the greater share of K-12 funding is obtained at the state level.

The public school funding model in Texas was constitutionally mandated in 1869 , but that original mandate was repealed in 1876 . Then, in 1883 , local districts were given the authority to levy property taxes by amendment to the state constitution (Bingham, 2008). Yet, even with a long history of court rulings and pending litigation over funding, the system remains unstable due to the reduction of state revenue and the rising cost of providing equitable education to all citizens (Imazeki \& Rechovsky, 2004). The economic recession further destabilized the state's funding system and affected school district budgets, resurrecting the debate on equality (Whittaker, 2011). In October 2012, over 600 Texas school districts joined in a lawsuit claiming the funding system was unconstitutional. In February 2013, a state district judge, John Dietz, ruled the state does not adequately or efficiently fund public schools and creates a financial burden at the local level (Smith \& Schneider, 2013).

While districts have had constant issues relating to revenue distribution, they have been somewhat shielded from the perturbations of economic downturns by biannual state budgets. However, the present prolonged recession has compounded the inherent far-reaching funding challenges requiring superintendents to choose between the status quo and making strategic cuts that will secure a progressive education system for future generations. Throughout Texas, districts are experiencing budget cuts which are impacting the delivery of quality education programs.

Moak, Casey and Associates (2011a), report on the American Association of School Administrators' survey findings found that approximately 2,900 school district jobs were eliminated from Texas schools in 2011 and over 60 percent of the state's school districts were expected to have to make additional staff reductions. In another study of 188 Texas districts, Moak, Casey, and Associates (2011b) found that the districts were serving 17,593 more students in the fall of 2011, and they were doing so with 3,219 fewer teachers and 6,367 fewer staff. In addition, this second report estimated that districts statewide in 2011 were employing as many as 32,000 fewer people including 12,000 teachers.

Across the state, newspapers, newsletters and blogs give readers a sense of the situations in which local school districts find themselves. For example, Taboada (2011), an education reporter and blogger for the Austin American Statesman, reported that painful budget cuts for the Austin Independent School District's 2011-2012 school year would (1) likely close some schools, and (2) likely declare financial exigency such that even contracted personnel could be terminate. Smith (2011) reported that special initiative programs such as "full-day pre-K to teacher incentives to high school completion efforts" (para. 3) were at risk of elimination when the Texas Education Agency 2012 to 2013 budget proposal included \$1.3 million reduction in discretionary grants. These are representative of the dire proposals and forced strategies that school districts and state agencies are using to navigate through the prolonged economic recession.

\subsection{What Others Have Done to Prepare for Economic Downturn}

States and K-12 administrators across the United States (U.S.) were forced to make changes that would limit damages created by the prolonged recession (Cavanagh, 2011). Developing a contingency plan in Texas might be perceived by some as a bit easier than in other places due to the legislature's biannual schedule and a financial cushion provided by the American Recovery and Reinvestment Act (ARRA) of 2009. However, challenges still prevailed.

The easiest strategy school superintendents had at their disposal was to make budget cuts that would inevitably erode the quality of education services. Unfortunately, such cuts would have repercussions for years to come. 
According to Petrilli and Roza (2011), a more thoughtful approach would be one that potentially protects the quality of education for the long run and starts reforms that were not possible in previous years. Closing such budget gaps presents an opportunity that encourages "unlocking commitments, policies, practices, and habits such that available education dollars can be used differently to better serve students" (Petrilli \& Roza, 2011).

Specifically, Petrilli and Roza (2011) proposed a variety of actions that could be used to make limited school funds go further. For example, they recommended ending last hired/first fired practices, and eliminating the standard salary schedules for employees. Petrilli and Roza (2011) further suggested that schools could also save money by adjusting instructional offerings by, for example, removing "seat time" requirements and class size mandates, limiting the length of time a student can be identified as an English Language Learner (ELL), allocating spending for learning disabled students as a percent of the population, and moving toward weighted student funding. States could help by providing waivers for state requirements that are deemed non-productive and/or easing reporting requirements, Finally, Petrilli and Roza (2011) suggested pooling health-care benefits, reviewing the teacher pension system, and eliminating excess spending on small schools and districts.

\subsection{What Others Have Done in Reaction to Economic Downturn}

The financial downturn had devastating impacts on the Texas education biannual budget (2011/2012). For the first time in 60 years, the legislature failed to finance estimated cost of fulfilling mandates under current law; Foundation School Program state aid was decreased by $\$ 4$ billion; Special Program financing was decreased by $\$ 1.3$ billion and Teacher Retirement System financing was decreased by $\$ 300$ million. The total decrease was $\$ 5.4$ billion when the cost of enrollment growth, property value decline, and other factors were taken into account (Moak et al., 2011a).

Local districts have weathered the economic storm by controlling payroll and non-payroll expenses. To facilitate cost cutting measures, the Texas state legislature passed Senate Bill 8 that gave districts flexibility in altering payroll expenses through hiring freezes, salary freezes, reviewing employee benefits and reviewing strategies for reducing or eliminating staffing positions (Walsh et al., 2011; Moak et al., 2011b). Non-staffing expenses that were reduced included "travel allowances, out of district student field trips, athletic expenditures, professional services, teaching material expenses student transportation cost" (Moak et al., 2011a, pp. 25-30). These changes have most certainly affected the quality of education services provided by K-12 institutions as districts, principals and teachers strive to both minimize long-term effects on student learning while concurrently developing strategies/protocols to keep both programs and staff from being eliminated.

\section{Methods}

This study explored how selected Texas superintendents planned for and reacted to the budget downturn. Three research questions guided this study. (a) How did the superintendents face these budgetary challenges? (b) What type of planning was put in place before the cuts? (c) How would they deal with budget cuts differently in the future?

Texas is comprised of 20 different regions. For this study, 20 superintendents were chosen from each region and invited to participate in an online survey about the effects of the financial downturn on their districts. A total of 400 superintendents were contacted by email and invited to participate in the survey.

The source of data was an online survey. A secure, online system, psychdata.com, was utilized to gather participant responses. The first survey questions solicited basic descriptive information about both the respondent and his/her school district. The survey questions about the respondent and the school district were analyzed for descriptive statistics. To ascertain superintendents' perceptions of their district's financial position, each was asked, in open-ended questions, to describe the ways in which they had planned for and responded to the budget cuts. The responses to the open ended questions were coded for patterns in accordance with qualitative methodology. The descriptive data and the emerging themes were cross checked and reviewed for commonalities and/or places where the data intersected (Wolcott, 2009).

Of the 400 superintendents invited to participate, 79 responded to the survey and provided information regarding how they have handled the financial crisis. Of the responding superintendent pool, 56 (70.8\%) were male and 23 (29.1\%) female. Superintendent tenure in their current district ranged from two months to 20 years; an average of 6.34 years experience.

\section{Findings}

In addition to demographic information, superintendents were asked to respond to open ended questions. Open-ended responses were coded and analyzed for patterns and themes. From gathered data, four main themes 
emerged. First, participating superintendents described the effects of recent funding cuts on their district. Second, superintendents described how their districts fared in relation to other districts. Third, they explained how they had planned for the funding cuts. Fourth, they explored what they wished they had done.

\subsection{Please Describe the Effects of the Recent Funding Cuts for Your School District}

In response to the first question asking how they believed their district fared in comparison with other districts, 62 district leaders responded. Of those, 23 (37\%) superintendents indicated their districts were better off, while $18(28 \%)$ felt they were worse off, and, $21(33 \%)$ believed they were in the same situation as neighboring districts.

Several of those superintendents who stated their districts were better off cited the presence of a fund balance that was in place prior to the cuts. One stated, "We were fortunate to have passed a Tax rollback election in 2006 that allowed us to set our Maintenance \& Operations ( $M$ \& O) tax rate at \$1.17. Districts that have not passed an election must set their $M \& O$ rate at $\$ 1.04$. Due to this higher rate, we have been able to accumulate a respectable fund balance to offset the decreased funding from the state." Another district indicated high growth worked in its favor, "......better because we are a high target district that is growing. While we saw a $\$ 20$ million cut from old funding formulas, due to our growth and conservative nature in budgeting, we balanced budget and will be able to have one time expenditures". Yet another stated property value increases impacted local funding in a positive way, "...fortunate compared to other school districts because we had about a $5 \%$ increase in our local property values".

Several districts cited long term planning as the reason for the positive position they found themselves in. Comments included, "Very well. We had a plan and followed it".

Two districts that stated that they fared worse than other districts cited lower property values in their area that impacted funding. Three superintendents discussed the return of money to the state due to being a Chapter 41 school district as having impacted them negatively through wealth equalization. Other comments from district leaders indicated their districts fared worse than those who surrounded them included issues such as property values decreasing in several cases. “...values declining by $20 \%$. We lost $\$ 113,000,000$ in values.” And, "Target revenue was lower than most in the area and many in the state". Another recurring issue from districts that reported being harder hit was that they were funded at a lower rate than surrounding districts to begin with. "We were already funded at a rate lower than the average district, so these cuts hurt us even more than most". "...lower level per student than many other districts across the state due to the way the state funding formula is written". Several districts indicated they had been hit harder due to their size. "We are a poor rural district and I believe that there are other districts in the suburban/urban areas that are faring much better than we are. It is my belief that the rich are getting richer and the poor are getting poorer". Finally, one leader stated the district was worse off in this way, "...raise the student/teacher ratio in math and ELA. We have coordinated with a surrounding district to share teachers so we can maintain an art program. These are tough times for Texas Schools!!"

\subsection{How Do You Think Your District Fared in Comparison with Other Districts? In What Ways Was Your Situation Better or Worse than Others?}

Interestingly, one district leader illuminated the angst of his situation saying, "Through proactive measures (reducing 18 professional positions for the last school year and 27 for the coming year), we should be able to adopt a balanced budget whereas many of our neighbors will be adopting a deficit budget. However, they will have more staff during this critical year of transition from TAKS to STAAR. Thus, while we may be better off financially this year, they may be better off in terms of being able to meet student needs without placing an overwhelming burden upon staff".

Of the $33.87 \%$ of superintendents who indicated their districts fared the same (financially) as those who surrounded them, responses were very similar. Many of these districts indicated the presence of an adequate fund balance that they were using to continue to operate at an acceptable level. One superintendent aptly stated, "All districts were hit hard by the budget cuts. Each district did their best to limit the negative impact it would have on educating our youth". Another noted, "I think all school districts and the communities they serve suffered." Many merely stated that they were, "better than some but worse than others..."

4.3 What Steps Did Your District Take before the Cuts Were Announced That You Think Made Your Situation Better? After the Cuts Were Announced?

The superintendents' responses to the inquiry about steps prior to the legislative cuts varied widely. The greatest percent, 59.6\%, reported that a reduction in staff was the way they responded to the impending budget cuts. 
Early cuts and strong communication weighed in at $37 \%$ of the responses while $12.5 \%$ opted for a hiring freeze. Superintendents attributed budget realignments in $24 \%$ of the cases due to attrition. Still others said that in depth study was the key $5 \%$ of the time. Other districts $(16 \%)$ opted to cut programs such as extracurricular activities or non-core classes rather than personnel. Lastly, no pay increase, exit incentive, adding to fund balance and always being frugal weighed in at $2.5 \%$ each.

\subsection{What Do You Wish Your District Had Done?}

When asked what they wished their districts had done, the superintendents were generally of one voice, that is, $82 \%$ of those who responded indicated that they would not have done anything differently. However, a few (6.4\%) indicated they wished that they had been able to keep the same staff knowing that the cuts were not as deep as first shown. Others (4.8\%) said that starting earlier was an option while cutting staff for another district was a choice (1.6\%). Another school leader indicated the wish to "wait on job notices, but it was the law" (1.6\%). In response to what could be done differently, one leader stated, "Impressed upon the Legislature that funding education in Texas is a mandate not an entitlement program." There were some respondents who did not answer this open-ended question.

\section{Discussion}

While this study suggests that the process by which superintendents dealt with the budget crisis varied greatly, it is evident by the responses that those who began planning earlier reported that they fared better than surrounding districts. Based upon this, it seems that strategic planning in association with budgeting is essential. Strategic planning specifically addresses the fact that a system must be responsive to a dynamic and changing environment (Chang, 2006).

Overwhelmingly, the greatest response to the budget crisis was a reduction in staff. Most (79\%) districts reported cutting personnel costs with attrition or a reduction in force or a combination of the two. However, according to these district leaders, this move is not without consequences. For example, one stated, "43 positions were eliminated or not filled. Resulted in a loss of over 1,000 years experience."

This study suggests the primary challenge the Texas superintendents faced was that of meeting effectively the state mandated accountability standards with shrinking financial resources. The challenges of budget shortfalls were both compelling and painful. As one CEO stated, "We have increased class sizes and eliminated intervention programs. The new testing standards were certainly adopted and will move ahead as planned; however, with fewer resources, the deck is stacked against the students". Ultimately, this expectation of doing more with less will impact student learning. While these district leaders did not share the direct impact of cuts on student success, further research is recommended specifically to determine if a connection exists between these cuts and student outcomes.

\section{References}

Bingham, W. (2008). Financing Texas Public Schools. In J. A. Vornberg (Ed.), Texas public school organization and administration (pp. 375-394). Dubuque, IA: Kendall Hunt Publishing Company.

Cavanagh, S. (2011). Education takes hit in budgets. Education Week, 30(36), 1. Retrieved from http://www.edweek.org/ew/toc/2011/07/13/index.html

Chang, G. (2006). Strategic planning in education: Some concepts and steps. Paris, France: UNESCO Press.

Ginsberg, R., \& Multon, K. (2011). Leading through a fiscal nightmare: The impact on principals and superintendents. Phi Delta Kappan, 92(8), 42-47.

Imazeki, J., \& Reschovsky, A. (2004). School finance reform in Texas: A never-ending story? In J. Yinger (Ed.), Helping children left behind: State aid and the pursuit of educational equity (pp. 251-282). Boston, MA: The MIT Press.

Moak, C., \& Associates. (2011). What districts are doing to reduce cost? Presentation to Texas Association of School Administrators/Texas Association of School Boards Annual Conference, Austin, Texas. Retrieved from http://www.moakcasey.com/articles/viewarticledoc.aspx?AID=2677\&DID=2657

Moak, C., \& Associates. (2011). How did state budget cuts impact school district staffing levels: Preliminary Information Retrieved December, 2011, from fromhttp://www.moakcasey.com/articles/viewarticledoc.aspx?AID=2677\&DID=2657 
Petrilli, M. J., \& Roza, M. (2011). Stretching the school dollar: A brief for state policymakers, Policy Brief. $\begin{array}{lllll}\text { Thomas } & \text { B. } & \text { Fordham } & \text { Institute. } & \text { Retrieved }\end{array}$ $\mathrm{http}: / /$ www.edexcellence.net/publications/stretching-the-school-dollar-policy-brief.html

Smith, M. (2011). Pre-K programs vulnerable as schools confront cuts. Texas Tribune. Retrieved from http://www.texastribune.org/texas-education/publiceducation/pre-k-programs-vulnerable-as-schools-confro nt-cuts

Smith, M., \& Schneider, E. (2013). Updated: School finance ruling favors districts. Retrieved from http://www.texastribune.org/2013/02/04/ruling-imminent-texas-school-finance-trial

Taboada, M. (2010). Austin schools superintendent establishes hiring freeze, board may declare financial exigency. Retrieved from http://www.statesman.com/news/news/local/austin-schools-superintendent-proposes-job-cuts-de/nRfrz

Texas Education Agency. (2011). School finance 101: Funding of Texas public schools. Retrieved from Texas Education Agency. Retrieved from http://www.tea.state.tx.us/index4.aspx?id=7022\&menu_id=645\&menu_id2=789

United States Government Accountability Office. (2010). Federal Education Funding: Overview of K-12 and Early Childhood Education Programs. Washington, DC: Government Printing Office. GAO-10 - 51.

Walsh, A., Brown, G., \& Green, P. C. (2011). $82^{\text {nd }}$ Texas Legislature Regular and $1^{\text {st }}$ Special Session: Bills Related to Education. Retrieved From http://www.walshanderson.com/pdfs/82nd_session.pdf

Whittaker, R. (2011). School Lawsuits Multiply. The Austin Chronicle. Retrieved from $\mathrm{http}: / / w w w . a u s t i n c h r o n i c l e . c o m / n e w s / 2011-11-04 /$ school-lawsuits-multiply

Wolcott, H. F. (2009). Writing up qualitative research (3rd ed.). Thousand Oaks, CA: Sage.

\section{Copyrights}

Copyright for this article is retained by the author(s), with first publication rights granted to the journal.

This is an open-access article distributed under the terms and conditions of the Creative Commons Attribution license (http://creativecommons.org/licenses/by/3.0/). 